\title{
LIC 法を利用した鉛筆画の自動生成法
}

Automatic Generation of Pencil Drawings Using Line Integral Convolution

茅 暁陽, 長坂 好恭, 山本 茂文, 今宮 淳美

Xiaoyang Mao, Yoshiyasu Nagasaka, Shigefumi Yamamoto, Atsumi Imamiya

山梨大学工学部コンピュータメディア工学科

Department of Computer and Media Engineering, Yamanashi University

\section{概 要}

本論文は，流れ場の可視化手法として近年注目されている LIC（Line Integral Convolution）法を利用し， 2 次元画像を自動的に鉛筆画に変換する手法を提案する. LIC 法では, 流線上に定義されているローパスフィ ルタを用いてホワイトノイズを畳み込む処理を行うため, 出力画像には明るさにばらつきをもった線状の軌 跡が見える.このような軌跡で鉛筆のストロークを近似し，入力画像のトーンにマッチしたホワイトノイズ とストロークの方向を表すべクトル場に LIC 法を適用することで鉛筆画を生成する. 従来の CG による鉛筆画 の表現法は，個々のストロークをポリラインという幾何学的プリミティブを用いて表現するため，複雑なデ 一タ構造が必要な上に，トーンのマッチングやクリッピング処理などにも多くの時間を要していた。それに 比べて提案手法は，簡単なフィルタリング処理を施すだけで入力画像にマッチしたトーンをもった鉛筆画を 生成することができる. 本論文ではさらに，入力画像のテクスチャをより自然に表すためのストローク方向 決定法も併せて提案する.

\begin{abstract} convey the textures of objects appropriately.

キーワード

ノンフォトリアリスティック，絵画風画像生成，鉛筆画，LIC
\end{abstract}

In this paper, we propose a new technique for automatically generating pencil drawing from 2D images using line integral convolution. Our idea is inspired by the similarity between the stroke textures of pencil drawings and the flow textures generated with line integral convolution. We succeeded in creating pencil drawings with their tone matching that of the original images simply by taking the vector field defining stroke directions and the white noise images generated by referring to the intensity of the original images as the input to the line integral convolution algorithm. By employing the texture analysis techniques, we also succeeded in automatically orienting strokes in the directions that

Keyword

non-photo-realistic rendering, pencil drawing, artistic media, line integral convolution 


\section{1. はじめに}

近年, 非写実的レンダリング

(Non-Photorealistic Rendering : NPR) は，コンピ ユータグラフィックス研究における最重要課題のひ とつとして注目されている [1-2]. 油彩 [3], 印象 派絵画 [4]，水彩画 [5]，ペンとインクなどによる イラスト画作成 [6-12]，(色)鉛筆画 [13-17] など， 伝統的な芸術メディアやスタイルをモデル化する多 くの技法が提案されている，本論文では，与えられ た写真や 2 次元画像から鉛筆画風の画像を自動的に 生成する新しい手法を提案する、鉛筆画は下書き用 のスケッチだけでなく, 完成された作品にも利用さ れる、鉛筆画がもつ無彩色のトーンや未完成の風合 いは見る者の好奇心や想像力を掻き立てる．鉛筆画 は芸術に限らず，服飾や建築設計，科学技術用イラ スト画作成にも幅広く利用されている.

鉛筆画を扱っている既存の NPR 技法を振り返って みる. PencilSketch とよばれる初期の 2 次元システ ム[17]では，マウスをべースとした仮想タブレット 上で，ユーザは対話的に鉛筆の硬度，筆圧，ストロ ークの方向等の描画パラメータ值を指定する. 最近 では, Sousa と Buchanan が実際の鉛筆画の顕微鏡写 真を観察した結果に基づいて，鉛筆，紙，そして両 者間の相互作用に関するモデルを開発している [15-16]. モデルパラメータ值とストロークが決まる と, 与えられた 2 次元画像が対応する鉛筆画に変換 される [15].また 3 次元のポリゴンモデルも，モデ ルのパラメータ值からトーン值を決める参照テーブ ルを用いて, 自動的に鉛筆画に高速変換される $[16]$. 一方で高木と藤代 [13-14]は, 3 次元ボリュームを用 いてモデル化された紙の微細構造と顔料分布を, ボ リュームレイトレーシングでレンダリングする方式 を提案した．これ以外にも，ペンとインクによるイ ラス卜画作成の一連の成果 [6-12] は, 本論文の手法 に関連する NPR 技法である.

既存の鉛筆画生成技法とペンとインクによるイ ラスト画生成技法はすべて, 幾何学ベースか画像べ 一スか，あるいはユーザによる介入が必要かどうか という, 主要な 2 つの観点から分類できる. 幾何学 ベースの技法は 3 次元シーンの記述を入力とする.
通常 3 次元幾何学データとビューイング情報があれ ば，サーフェイスのトーンやオブジェクトの 3 次元 形状を的確に伝えるストロークをもった画像を自動 的に生成することができる，一方，画像ベースの技 法は 2 次元画像を直接的に処理して, 芸術的な表情 付けやイラストの効果を創り出す。この場合は，基 礎となる 3 次元幾何学情報やビューイングパラメー タが与えられていないため, 自動生成は比較的困難 であり，ほとんどの手法では，ストロークテクスチ ヤを決定する上で少なからずユーザの介入を必要と する. 2 次元濃淡画像を自動的にペン画像に変換す る手法として中川[12]らの手法がある。この手法で は線描画風ペン画と点描画風ペン画を自動生成でき る. 線描画風ペン画の場合は単一方向に描かれてい るストロークテクスチャか, 濃淡の勾配を求めるこ とにより検出した入力画像のテクスチャの流れにそ ったストロークテクスチャを使用する。またあらか じめ用意した単一方向のストロークテクスチャをユ ーザが指定したガイドラインにそってワーピングす ることにより任意の方向に流れるストロークを生成 することも可能である.

本論文で提案する手法も画像ベースに属し，2 次 元濃淡画像を鉛筆画風画像に自動変換する. 本手法 の最大な特徵は近年流れの可視化に広く利用され始 めた線積分畳込み法（Line Integral Convolution: LIC）［18]の利用である. ポリラインのような幾何学 的プリミティブを用いてストロークを生成する代わ り，画素ごとにローパスフィルタをかけるだけで鉛 筆画を生成することができ，ストロークのスキャン 変換, アンチエイリアシング, クリッピング等の煩 雑な処理が必要なく, 実装も容易である。また，事 前に諧調テクスチャを用意する手法 $[12,15,16]$ や差 分画像を使ってストローク密度を制御する手法 $[7,8]$ に比ベトーンのマッチングが容易に行えるこ とも特長の一つである.

本論文は, 次章以降以下のように構成されている. まず次章では，鉛筆画と LIC に関して簡単な導入を 行った後, LIC を利用して鉛筆画を生成する基本的 な考え方を説明する．第 3 章は提案手法の詳細であ る. LIC をべースとする鉛筆画を生成するプロセス 
を概観した後，自動システムを実装するための各要 素技術を詳しく述べる. 第 4 章では提案手法を用い て作成した画像例を示し, 提案手法の効果を検証す る. 最後に第 5 章で本論文をまとめ, 今後の研究課 題に言及する.

\section{LIC による鉛筆画生成}

\section{1 鉛筆画の基本要素}

鉛筆画の本質は, 主題となる要素の描画に, グレ イスケールのトーンだけを利用することである，異 なるレベルからなるトーンはストロークを描くこと によって得られる，個々のストロークの外見は，描 かれる紙の地合い, 鉛筆の硬度, 鉛筆の芯先が紙に どのように触れるかということに依存している $[20,22]$.

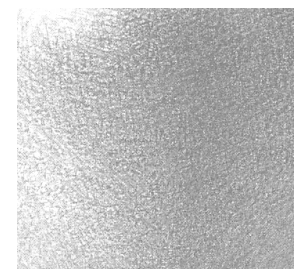

(a)

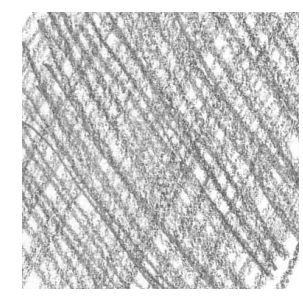

(c)

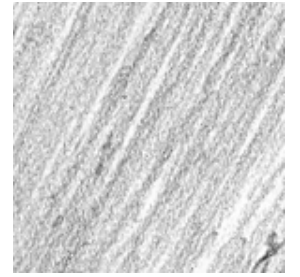

(b)

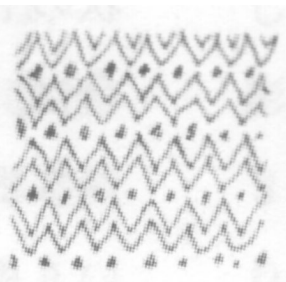

(d)
図 1：実際の鉛筆画の基本トーン.

(a) 写実的トーン,

(b) 平行ストロークによる模倣トーン

(c) クロスハ
よって描かれた模倣トーンの例を，それぞれ図 $1(b)$ と 1 (c) に示寸. 模倣トーンの場合は個々のストロー クがはっきりと残っているが，見る側の人間がス卜 ロークを混ぜ合わせ，滑らかな陰影を心理的に形成 する.この 2 種類の基本トーン以外にも，図 1 (d) に 示したような装飾用 (decorative) トーンがしばし ばオブジェクトの模様を表現するために利用される.

\section{2 LIC 法}

LIC 法は，1993 年に Cabral と Leedom によっ て提案された， 2 次元ベクトル場を可視化するテク スチャベース技法である．2 次元ベクトル場が規則 的な直交格子によって与えられたとする．LICアル ゴリズムは，そのベクトル場と同じサイズのホワイ トノイズを入力し， ベクトル場の方向にそって局所 的に滲んだようなテクスチャを出力する。ベクトル 場の格子セルと入出力画素との間には 1 対 1 の対応 が成り立っている．出力画像の各画素值を決定する 際に，対応する位置の格子セルを通過するような局 所流線を生成する。そして，その流線にそって定義 された 1 次元のローパスフィルタカーネルを用いて， 入力画像の流線上の画素を畳办込む. 図 2 (c) は，図 2 (a) のベクトル場と図 2 (b) のホワイトノイズから 生成した LIC 画像の例である. LIC 法は現在，流れ 場の大局的な性質とともに，局所的な特徵の詳細も 表現できる手法として注目されている.

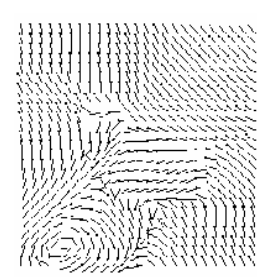

(a)

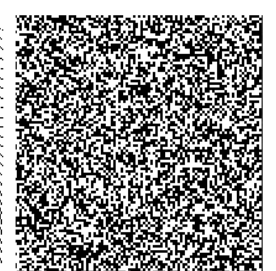

(b)

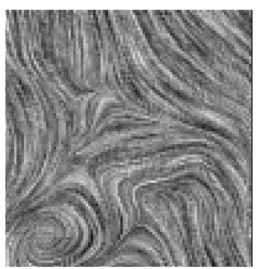

(c)
鉛筆画では, 主に 2 種類の基本トーンが使われて いる [20].ひとつは写実的トーン (realistic tone) である．図1(a)にその例を示す，写実的トーンは， 対象となる要素の陰影をなるべく忠実に再現する場 合に利用され，通常は異なる方向のストロークを 個々が区別できなくなるまで重㸚て描くことで得ら れる。もうひとつは，模倣トーン (imitative tone) とよばれる. 平行ストロークとクロスハッチングに
図 2：LIC 画像の例. （a）ベクトル場, (b) 入カホ ワイトノィズ画像，(c) 出力画像.

2.3 LIC 画像を用いた基本トーンの表現 鉛筆画を生成するために LIC 法を利用するとい う基本アイディアを説明する。まず図 3 を見てほし い. 図 3 (a) は，実際の鉛筆画に使われている典型的 な模倣トーンをデジタルサンプリングしたものであ 
る. その画像全体を眺めてみると，平行なストロー クによって，グレイスケールのトーンができあがっ ていることがわかる。，一方，その画像の任意の部分 領域に目を凝らすと, ストロークの方向や画素の輝 度がランダムに変化していることがわかる.

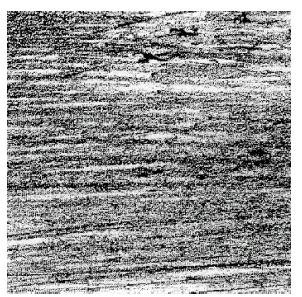

(a)

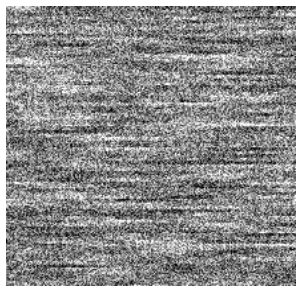

(b)
図 3: 実際の鉛筆画 (a) と LIC テクスチ ヤ(b) との比較.

この輝度変化は, 芯先と画用紙との相互作用の結果 である．実際芯先から剥がれて画用紙に付着する顔 料の量は, 紙の地合いの程度によってランダムに変 化するのである. この性質こそ，ペンとインクによ るイラスト画など他の画法がもちえない，鉛筆画独 特のやわらかくやさしい印象につながる最も重要な 要因のひとつである.ところが，同様のトーンの特 徵を LIC 画像も創り出していることがわかる（図 $3(b))$. LIC 画像は, 元画像をべクトル場から導出 される流線にそってローパスフィルタをかけること によって得られるので, 流線にそったストローク調 の軌跡が残る。一方，任意の局所領域内の画素の輝 度は，LICに入力されてきたホワイトノイズ画像の 性質を継承してランダムに変化する。 このような, LICテクスチャと実際の鉛筆画との相似性を考慮し て, 我々は複雑で時間のかかる物理シミュレーショ ンを実行することなしに，LICテクスチャを用いて 鉛筆画のトーンを模倣することにする，すなわち， 主題の要素のトーンにマッチしたホワイトノイズと ストロークの方向を与えるベクトル場を用意するだ けで，LIC アルゴリズムによって鉛筆画風の画像を 生成寸ることができるのである，図 4 は，LIC 法を 利用して生成した 3 種類の基本トーンである. 図 4 (a) は，各格子点で方向をランダムにとったベクト ル場を用いて生成した写実的トーンである. 平行な ベクトル場を用いることによって, 図 4(b)のような 平行ストロークの模倣トーンを生成することもでき
る.クロスハッチングの模倣トーンは，異なる方向 をもつ平行ストロークのトーンを何枚か重㸚ること によって得ることができる（図 4(c)）．さらに，LIC 計算に用いられるパラメータ值を調整することで, 特定の視覚効果を簡単に追加することもできる．例 えば，荒い粒度のノイズを利用すれば，太いストロ ークを使った効果が出せる，また，畳み込みカーネ ルの長さを変化させれば，ストロークの平均長を変 えることもできる.

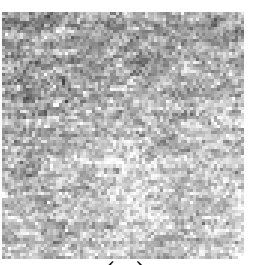

(a)

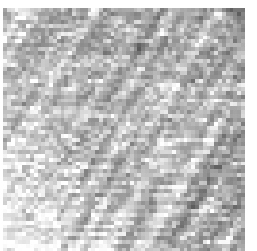

(b)

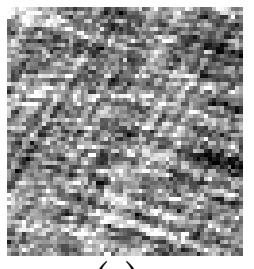

(c)
図 4：LIC 法で生成した基本トーン.（a）写実的トーン, （b）平行ストロークの模倣トーン，（c）クロスハッチ の模倣トーン.

絵画風画像生成における LIC の利用はほかにもい くつか存在する. 高木らは LIC 法を利用して色鉛筆 画生成における加水効果をシミュレートしている [13-14]. ブラシストロークの速度と水の性質をフィ ルタカーネルの長さに, 各ボクセルが貢献する顔料 の量をフィルタカーネルの重みにマッピングし，八 イトフィールドに対して LIC 計算を行うことで，加 水効果よる顔料の再分布を擬似的に表現した.

\section{LIC 法を用いた鉛筆画生成}

\section{1 アルゴリズム}

本節では，LIC 法を用いて自動的に濃淡画像から 鉛筆画を生成する過程を説明する. 入力画像がカラ 一画像の場合はまずそれを濃淡画像に変換する。図 5 に示すように, 生成過程は以下の 7 ステップから 構成されている：

1. 入力画像（図 5(a)）からホワイトノイズ画像 （図 5 (b)）を生成する;

2. 入力画像（図 5(a)）を異なる領域（図 5(c)） に分解する ;

3. 領域の境界を抽出する（図 5(d)）; 


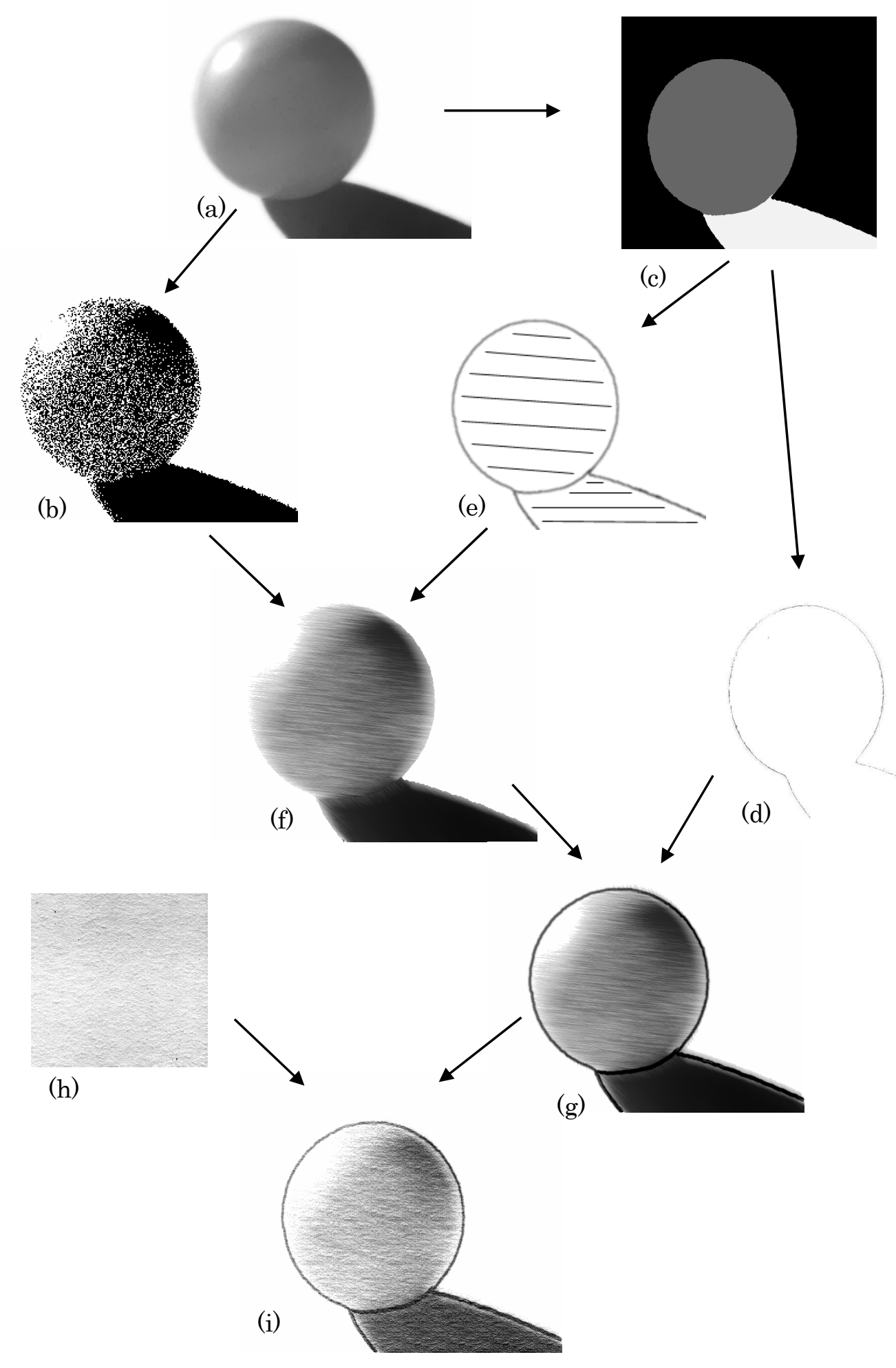

図 $5:$ LIC ベースの鉛筆画生成手続き. 
4. ストロークの方向を示す心゙クトル場（図 5(e)） を生成する；

5. ホワイトノイズ画像（図 5(b)）とベクトル場

（図 5(e)）から LIC 法によって鉛筆画（図 5 (f)）を生成する；

6. 必要に応じて, 境界（図 5(d)) を結果画像（図 $5(\mathrm{f}))$ に加え, 輪郭を強調した画像（図 $5(\mathrm{~g})$ ) を生成する；

7. 結果画像（図 $5(\mathrm{~g})$ ) に画用紙のサンプル

$5(\mathrm{~h})$ ) を合成し, 最終画像（図 5(i)) を得る.

ステップごとに後続の節で各々詳述する.

\section{2 ホワイトノイズ}

鉛筆画の最終結果のグレイスケールトーンは, 入 力されるホワイトノイズ画像によってほとんど決ま ってしまう. 入力画像と結果の鉛筆画のトーンを一 致させるために，入力画像のトーンを用いてノイズ の分布を決めることにする. ホワイトノイズ画像は, 白の画素が現れる確率を入力画像の対応画素の輝度 レベルに比例するようにとることによって得られる。

$I_{\text {input }}$ を入力画像のある画素の輝度とする.Pを擬似 乱数関数によって得られた $[0.0,1.0]$ の範囲の浮動 小数点数とする.ノイズ画像の対応画素の輝度 $I_{\text {noise }}$ は，以下の式にしたがって計算される：

$$
\begin{aligned}
& I_{\text {noise }}=\left\{\begin{array}{cl}
255 & \text { if } \quad P \geq T \\
0 & \text { otherwise }
\end{array} \quad P \in[0.0,1.0]\right. \\
& T=k\left(1-\frac{I_{\text {input }}}{255}\right) \quad k \in(0.0,1.0]
\end{aligned}
$$

ここで， $k$ は結果の鉛筆画の全体的明るさを決定す る係数である. カーネル形状の積分值を用いて LIC 計算の結果を正規化することで出力画像の明るさに 対するカーネルの影響を一定にしているが， $k$ の最 適值を決めるには，カーネルの形状や長さも考慮す る必要がある，結果の鉛筆画にローパスフィルタリ ングを施し入力画像との差を取り, その差が最小と なるような $\mathrm{k}$ が入力画像のトーンをもっとも正確に 表せるものであると考えられる，デフォルトでは，
長さ 20 ピクセルのボックスフィルタがカーネル関 数として使用されるが，この場合経験的に $\mathrm{k}$ を 0.7 前後に設定することでほとんどの画像に対して良好 な結果が得られる，ユーザは対話的に $k$ の值を調節 することもできる.

容易にトーンを合わせることができる点は，LIC 法を利用する最も大きな利点である，既存の鉛筆画 やペンとインクによる技法の多くは幾何学的なプリ ミティブを利用しているので, 連続的なトーンを得 るために，プリミティブの配置密度の調整に余計な 手間を要する，例えば，観察に基づく鉛筆画モデル [15-16] や中川らのペン画自動生成法 [12]は，予め 計算されたトーン值の参照テーブルを引用してマッ チングを行っているため，連続トーンを生成するこ とは難しい。 また Salisbury ら[7-8]によって提案 されたペンとインクによる技法は，差分画像を使っ てストローク密度を制御している. 入力画像を初期 值とする差分画像は，まずストロークを沴ませた画 像分を引かれる，続いて，差分画像内もっとも大き い值をもつ位置を次のストロークを置く場所とする. この処理は差分画像のすべての画素值が十分小さく なるまで繰り返さなければならない。これら既存の 技法と比較して，我々の手法はより簡単にトーンマ ッチングを実現している. 入力画像とホワイトイズ 画像の各画素をただ 1 回だけ参照すればよいため, 処理時間はきわめて短くてすむ.

\section{3 領域と境界の抽出}

トーンの微妙な配合に加え, 鉛筆画で 3 次元の奥行 き感やシーンを構成するオブジェクト間の位置関係 を伝える目的でよく利用されている技法として，輪 郭線を描いたり，ストロークの外見を変更して，隣 接領域の境界を強調することがあげられる。このよ うな効果を創り出すために, 既存のテクスチャベー スの画像セグメンテーション技法を利用して入力画 像をいくつかの小領域に分割し，個々の領域ごとに 異なるべクトル場を定義することにする. 現在の実 装では, 輝度ヒストグラムに基づくセグメンテーシ ヨン技法 [21]を使って領域を抽出している．入力 画像をまず小さな矩形領域に分割する. 次に似た輝 
度ヒストグラムをもつ隣接領域を統合する。このプ ロセスを統合可能な隣接領域が存在しないまで繰り 返す，輝度ヒストグラムの近似度は, 両者の各レベ ルの值の差の総和によって計算できる. この差が与 えられた閾値よりも小さければ $2 つ の$ 領域は統合さ れる. 図 6(b) は, その技法を用いて, 図 6(a) に 示された入力画像を分割した結果である. 図からわ かるように，砂利を敷いた領域や道の領域が，内部 にテクスチャをもっているにもかかわらず，きちん と抽出されていることがわかる. 図 6(c) は, 図 6(b) の結果に対して領域ごとに異なるストローク の方向を与え, LIC アルゴリズムを適用して生成し た鉛筆画である.よい領域分割結果が得られるかど うかは初期の分割ステップにおける矩形領域のサイ ズや統合ステップにおける近似度の閾值の設定にも 大きく依存する．これらのパラメータの最適值は入 力画像に依存し, 多くの場合, 試行錯誤に頼るほか ない. 分割ステップにおける矩形領域の最適サイズ は入力画像のテクスチャサイズに設定するのが望ま しい，テクスチャサイズを求める技術はいくつか知 られているので, これらを利用すれば、最適值の自 動設定も可能と思われる. 現在のデフォルト值は 5 $\times 5$ に設定されている.

NPR 画像が写実的な画像よりも優れているところ は, 抽象化や念入りな詳細度制御によって, ユーザ を必要な情報だけに注目させて, 余分なところを無 視させられることにある. 特に抽象化は, 鉛筆画に よるスケッチに欠かせない，これを実現するには， 入力画像の意味論的解析が必要となるが，それをユ 一ザの介入なしに実現することはきわめて難しい. 現在は, 領域抽出の最終段階で, 一定面積以下の小 領域を隣接する大きな領域に統合するようにしてい る.

輪郭抽出については, 領域境界だけでなく, 領域 の内部構造も表現するために, テクスチャエッジ検 出ではなく, 微分オペレータを利用している. 内部 輪郭線は, 領域内部のテクスチャを表現する上で重 要である. 図 6(c)では, 結果の LIC 画像に Sobe1 オペレータをほどこすことによって道路の格子模様 が検出できていることがわかる．微分オペレータに
より検出したエッジの濃度は隣接する領域の濃度の

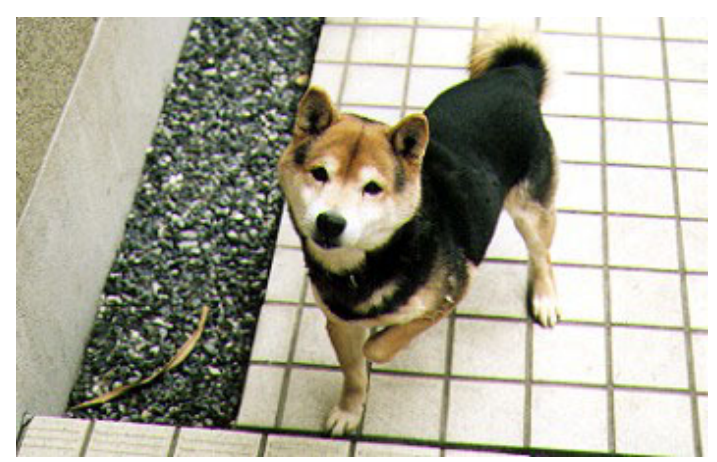

(a)

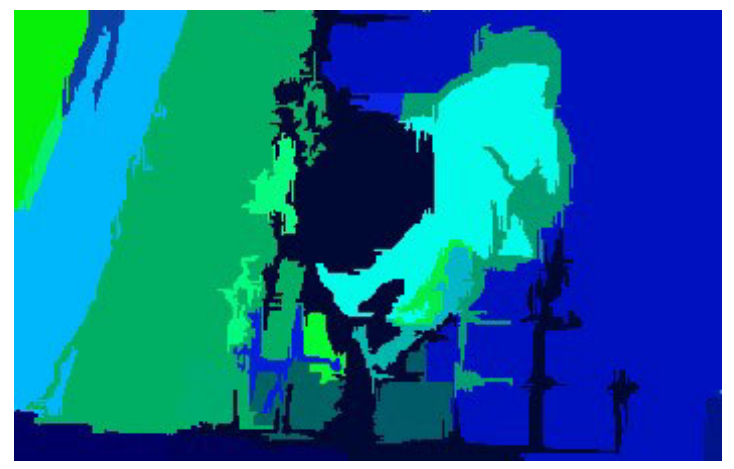

(b)

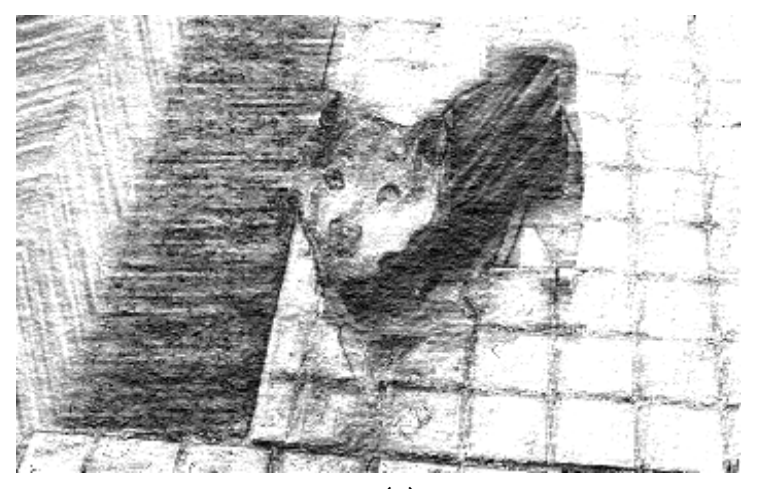

(c)

図 6：画像の領域分割.（a）入力画像；(b) 分割さ れた入力画像；(c) 領域ごとにストロークの方向を ランダムに与えて生成した鉛筆画。画像提供 : http://www.vector.co.jp/soft/data/art/se019516.html

差に依存する.人間が絵を描く場合は通常輪郭線を 領域内部よりも少し濃く描く傾向がある.これは検 出したエッジの各ピクセルに対して, その濃度を入 力画像における周辺ピクセルの濃度の平均值より高 く設定することで実現できる，また，実際に鉛筆画 を描く場合, 隣接領域のトーンの違いがあまり明確 でないほど境界線を強く描く場合もある $[22]$ 。これ 
を実現する方法としてエッジ画像の濃度を反転させ てから輪郭線として利用することが考えられる．現 在の実装では, Sobel オペレータを施した結果をそ のまま輪郭線画像として利用している.

\section{4 ストローク方向の決定}

模倣トーンを利用する場合, ストロークの方向は 鉛筆画らしさを決める重要な要素となる。またスト ロークの方向は, オブジェクトの形やテクスチャを 決める上でも重要である. もし，テクスチャが方向 性をもつとしたら，ストロークはテクスチャの方向 にそっていなければならない。例えば, 人間の頭髪 を描く場合，ストロークは髪が流れる方向を向いて いる必要がある.テクスチャの流れを検出し, それ に沿ったストロークを生成する手法はすでにいくつ か提案されている. 中川ら[12]のペン画生成手法で はSobel オペレータを用いて濃淡の勾配を検出する ことでテクスチャの方向を検出している. 齋藤ら [19]はフーリエテクスチャ解析法[21]を用いて局所 のテクスチャの流れを検出し, それをもとにストロ 一クの向きを決定する. 本システムで実装している 手法は斉藤らが利用したフーリエテクスチャ解析に よる手法とほぼ同じである。この方法では, テクス チャが方向性をもつならば, 周波数領域に変換した 後, そのパワースペルトルはテクスチャに直交する 方向に大きな值をもつという性質を利用する．従っ て, 各画素に対して局所テクスチャ方向を決定する ために，その画素を中心とする正方形ウィンドウを とり, 周波数領域に変換する. そして, 周波数領域 を小さな角度でセクタに分割し, パワーの総和の最 大值をもつセクタを決定する. 最後にこのピーク值 の全セクタの平均值との比を求め, 閾值よりも大き い場合には, そのセクタと直交する方向をその画素 におけるテクスチャの方向とする。もし閾值以下の 場合には, テクスチャは方向性をもたないとし, そ のピクセルを含む領域に対してランダムに設定され た方向を使用する.フーリエ解析を施す空領域のサ イズの最適值は入力画像のテクスチャにも依存する が，一般に小さすぎると，テクスチャの統計的な特 性を表すことができず，ピクセルの位置に依存して
正しいテクスチャの方向が得られない場合がある. 一方大きすぎると, 局所的なテクスチャ方向が抽出 できない問題がある. 現在の実装では，この窓領域 サイズもユーザが対話的に設定できる，デフォルト 值は $18 \times 18$ に設定されている.図 7 に示寸例では, この技法によって自動的に図 7(a)の木目から図7

（b）のストロークが生成できている.

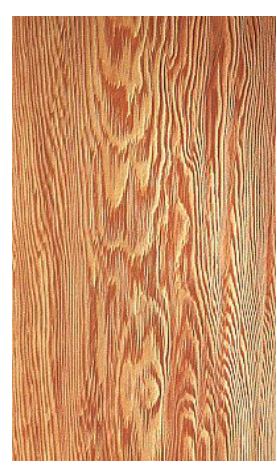

(a)

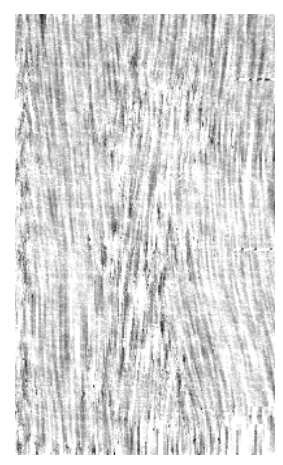

(b)
図 7 : 入カテクスチャ (a)の方向から自動的に生 成された ストローク (b).

\section{5 紙のモデル}

言うまでもなく, 鉛筆画の品質は, 画用紙の地合 いに大きく依存している. 紙の微細構造を観察する と, 紙表面には高低差がある。それが原因となって 鉛筆の芯先から顔料が削り取られ付着する。このよ うな紙の微細構造をモデル化する試みがこれまでに も続けられてきたが，典型的には紙の地合いをハイ トフィールドで表現している $[5,13,14]$. Sousa と Buchman は, 紙のデジタルサンプルのグレイスケー ル值からそのようなハイトフィールドを近似的に求 めている $[15]$. ここでは, より簡単に直感的な方法 を用いて, 紙の地合いの影響を含めることにした。 実際, 我々は結果の LIC 画像から紙のデジタルサン プル画像の差分をとり, 明るさを補正することで, 実用上十分な品質の画像を得ている。実際, デジタ ル化された紙のサンプルにおける陰影は, ハイトフ ィールドの山と谷によって決まり, それは画用紙に 顔料が付着する量とも直接的な関係をもっているこ とから，この方法は簡便ながら, 鉛筆画の物理的原 理にも合致したものであるといえる. 図 8(a) と (b)に示した紙のサンプルを用いて得られた鉛筆画 
をそれぞれ図 8(c) と（d)に示す。

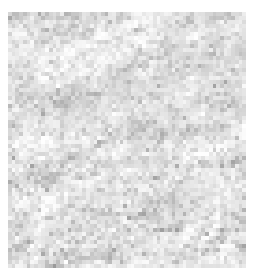

(a)

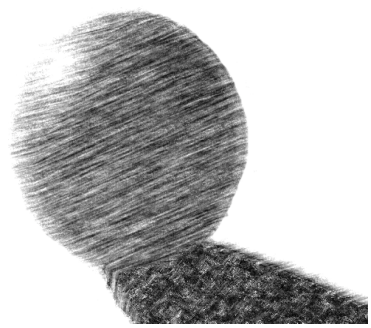

(c)

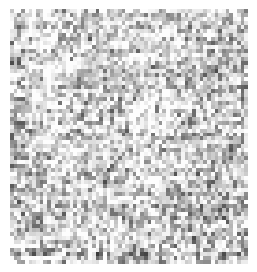

(b)

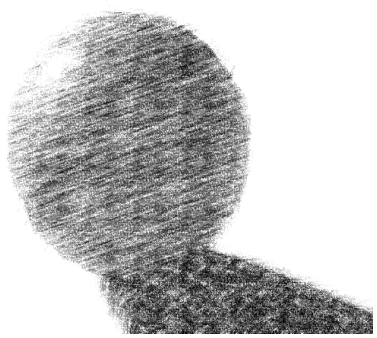

(d)
図 8：画像 (c) と (d) はそれぞれデジタル化さ れた紙のサンプル (a) と (b) を合成して得られ た鉛筆画.

\section{4. 実験結果}

我々は，第 3 章で述べてきた技法を実装し， Windows アプリケーションとして鉛筆画自動生成シ ステムを開発した. 入力画像が指定されると, デフ オルト值と入力画像からシステムが導出した值とを 用いて，自動的に対応する鉛筆画が生成される。工 一ザは, 画像全体の明るさ, 領域分割するための領 域サイズと近似度閾值，ストロークの太さと長さを 決定するためのホワイトノイズの粒度, 畳み込み力 一ネルの長さ等のパラメータ值を対話的に指定する ことができる.ただし，これらのパラメータは画像 全体に対して設定され，現在のところ，領域によっ てストロークの太さや長さを変えることができない. また，デフォルトで設定されている值は必ずしも最 適なものではない。自分自身のスタイルで描きたい ユーザは，マウスで境界線を指定することにより領 域を指定し，領域ごとに一本のサンプルストローク を描くことでストロークの方向を指定することがで きる. なお，本論文に示した画像については，領域 とストロークの指定に関して一切ユーザの介入がな かった。
図 9 (b) と（c) は, 図 9(a)の写真から生成された 2 枚の鉛筆画である. 図 9 (b) を生成する際，パワー ピーク比を決める閾值は最低值としたため, 各画素 におけるストロークは必ず最大パワーセクタと直交 する方向にとられている (3.4 節参照). 雲のテクス チャは特定の方向をもたないので, 各画素に対して ほとんどランダムのストロークが選択されており， ちょうど写実的トーンを用いた実際の鉛筆画のよう な風合いを出すことに成功している. 一方, 図 9 (c) は領域ごとにランダムに決められた方向のストロー クが使われているので, 平行ストロークによる模倣 トーンを用いた効果が表出している．ストローク方 向の決定法を除いて，この 2 枚の画像生成に使用し たそのほかのパラメータ值はすべて同じである．ど ちらの画像からも，実際の鉛筆画における消しゴム 効果( erasing) が得られていることに注意されたい. 消しゴム効果はハイライトによく用いられる $[20]$. 図 5 と図 8 のボールの画像でも, ハイライトの自 然な表現が，LIC 法によって一切の付加的な計算な しに実現できている。図 10(b) は, 図 $10(a)$ の写 真から自動的に生成された鉛筆画である。テクスチ ヤの方向選択によって，樹木や山々のテクスチャが 区別して描かれている.さらに自動的に検出された 領域輪郭も，画像の品質向上に貢献している.

図 6(c)に示した画像の解像度は $352 \times 228$ であ り，PentiumIIIXeon 933MHz のPC を用いておよそ 1 分で全処理が計算できている. 図 9 の画像の解像度 は $1024 \times 768$ であり，同じ環境で，図 9(b)と（c)の 鉛筆画を得るのにおよそ 20 分を要した.解像度が高 い場合の処理の遅さが目立つが，全計算時間の $90 \%$ は画像の領域分割に要しており，5\%はテクスチャの 方向を決定することに費やされている. 図 10 の画 像解像度は $1024 \times 768$ であるが，局所テクスチャの 方向をそのまま各画素に用いているため，画像セグ メンテーションのステップを省略することができた 結果, 全実行時間は 1 分 25 秒ですんだ. 領域分割コ 一ドの最適化によって処理速度を劇的に改良するこ とができると考えられる。また，より高速な領域分 割法について現在調査を行っている. 


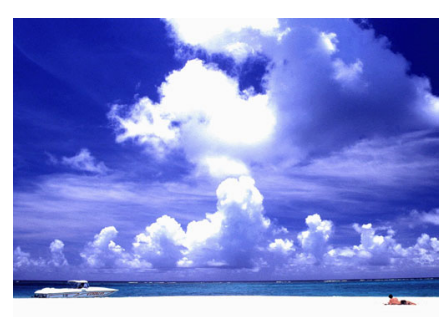

(a)

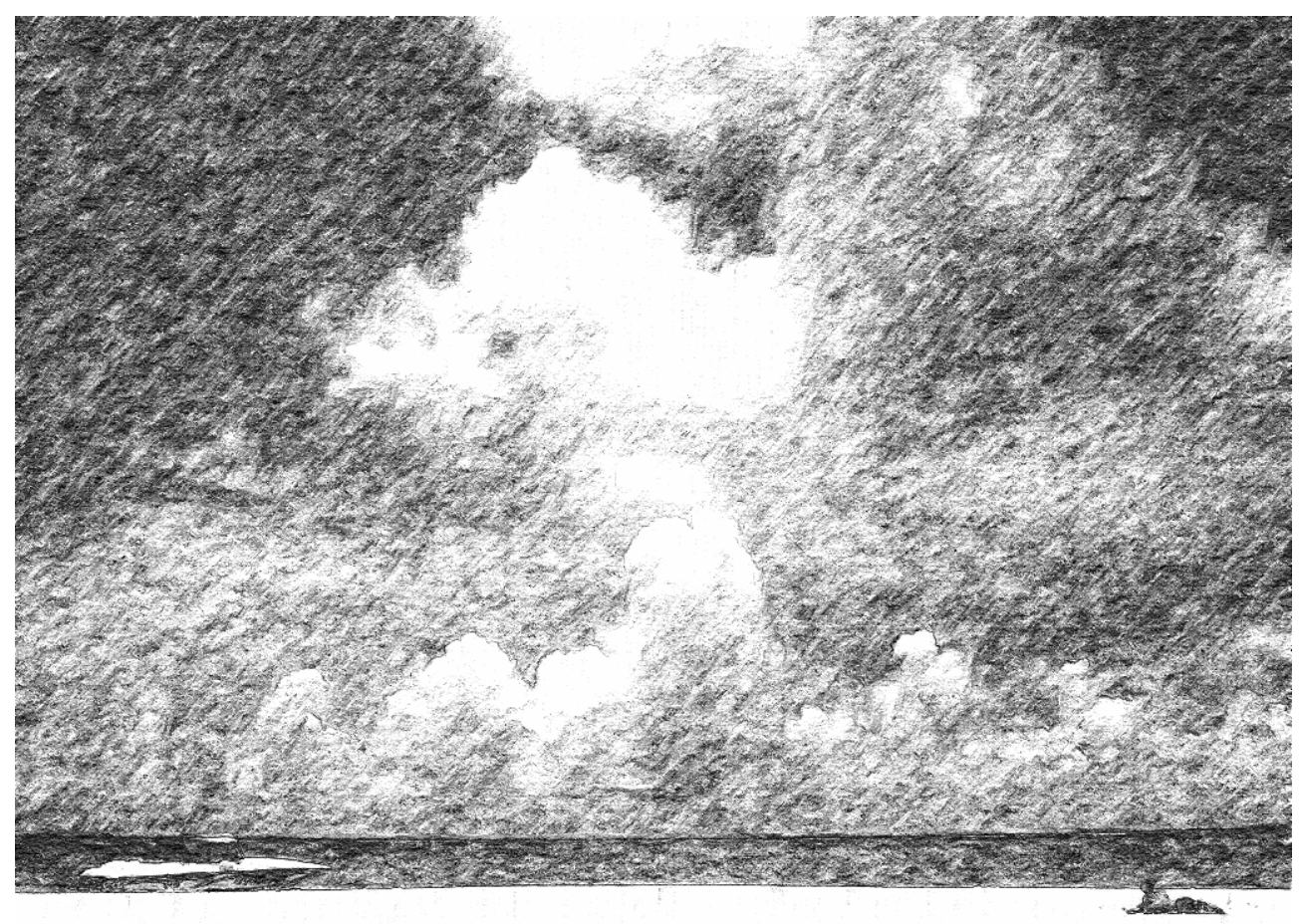

(b)

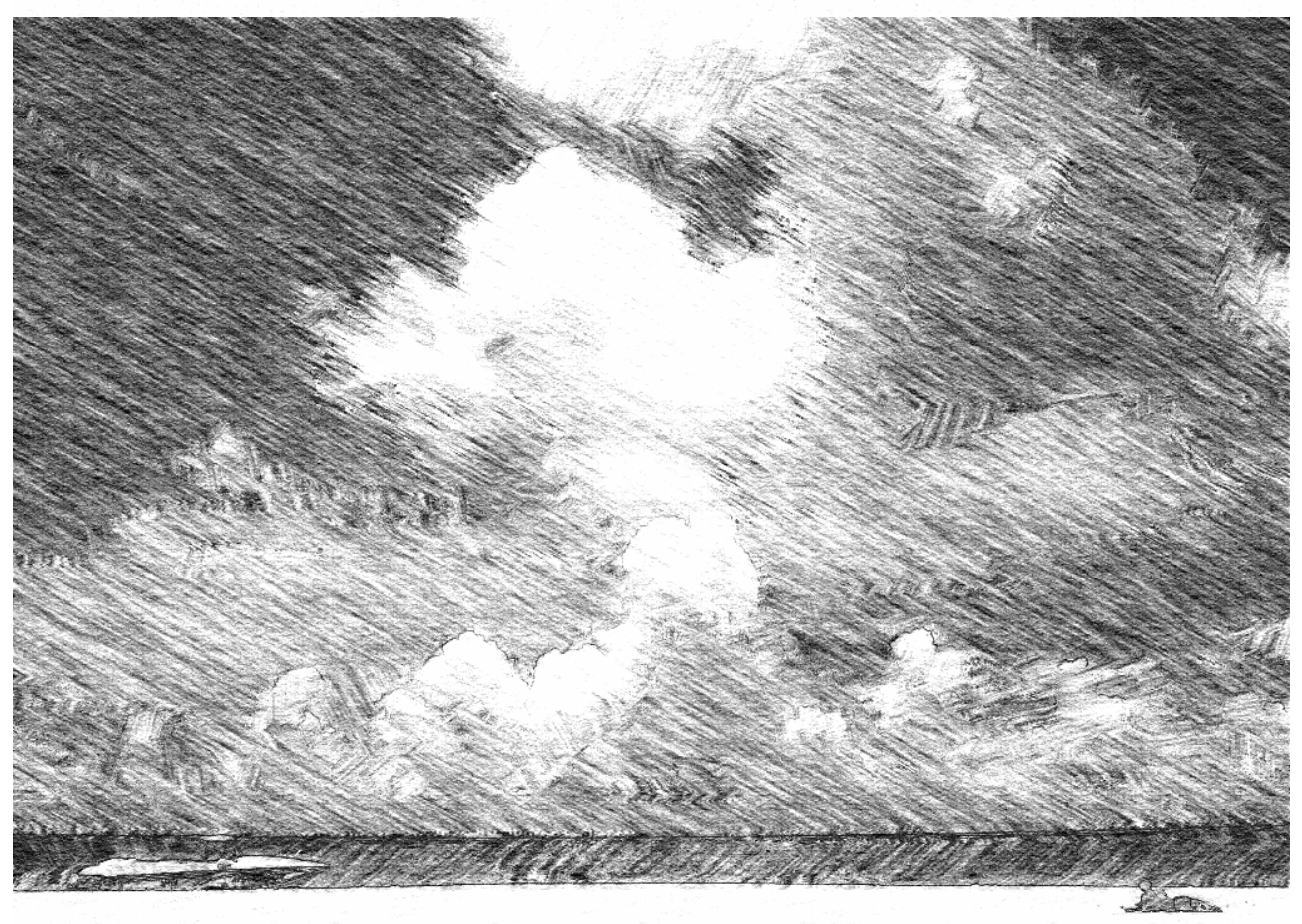

(c)

図 9: 入力画像(a)から生成された鉛筆画(b)と(c).

画像提供 : http://www.vector.co.jp/soft/data/art/se079521.html 


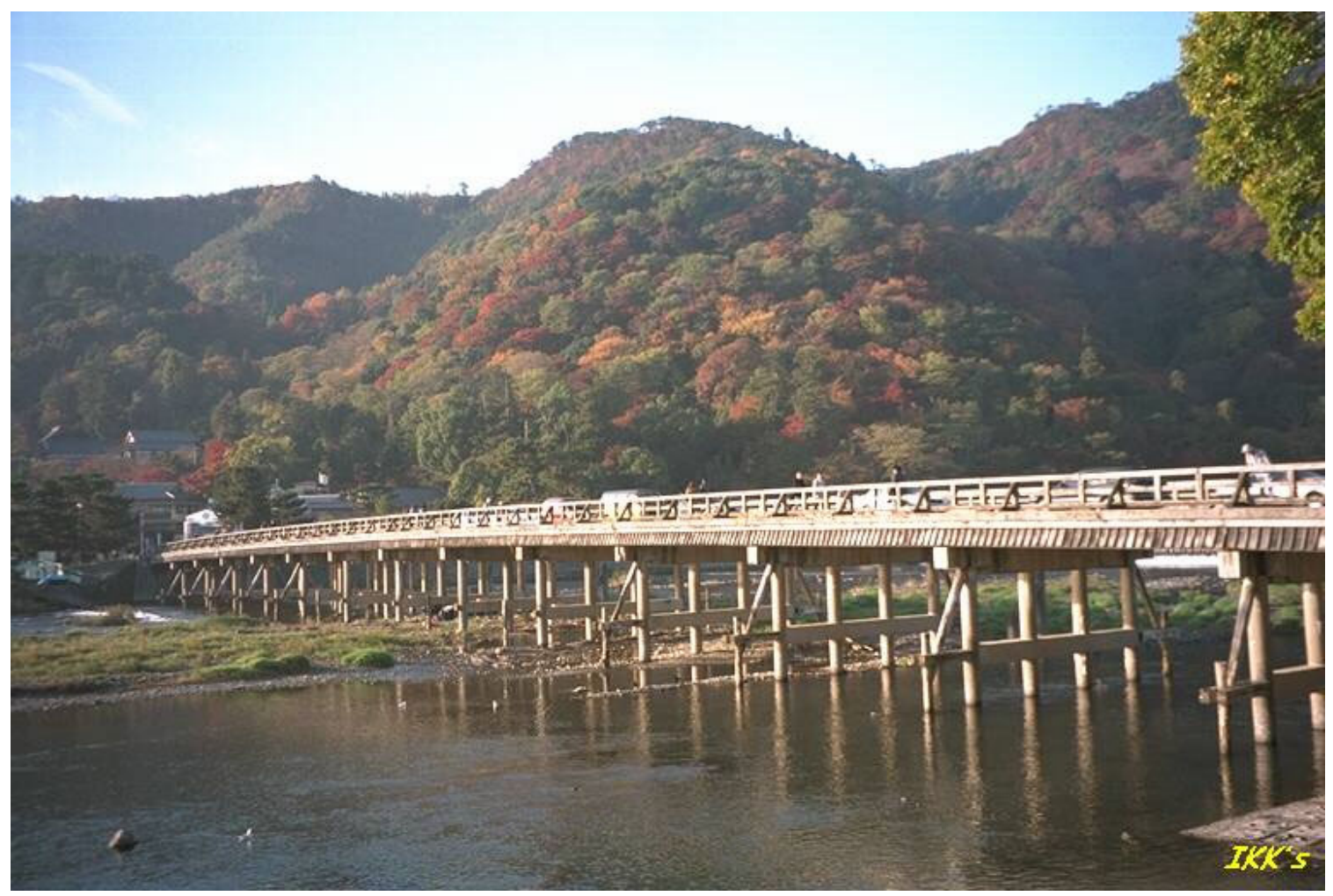

(a)

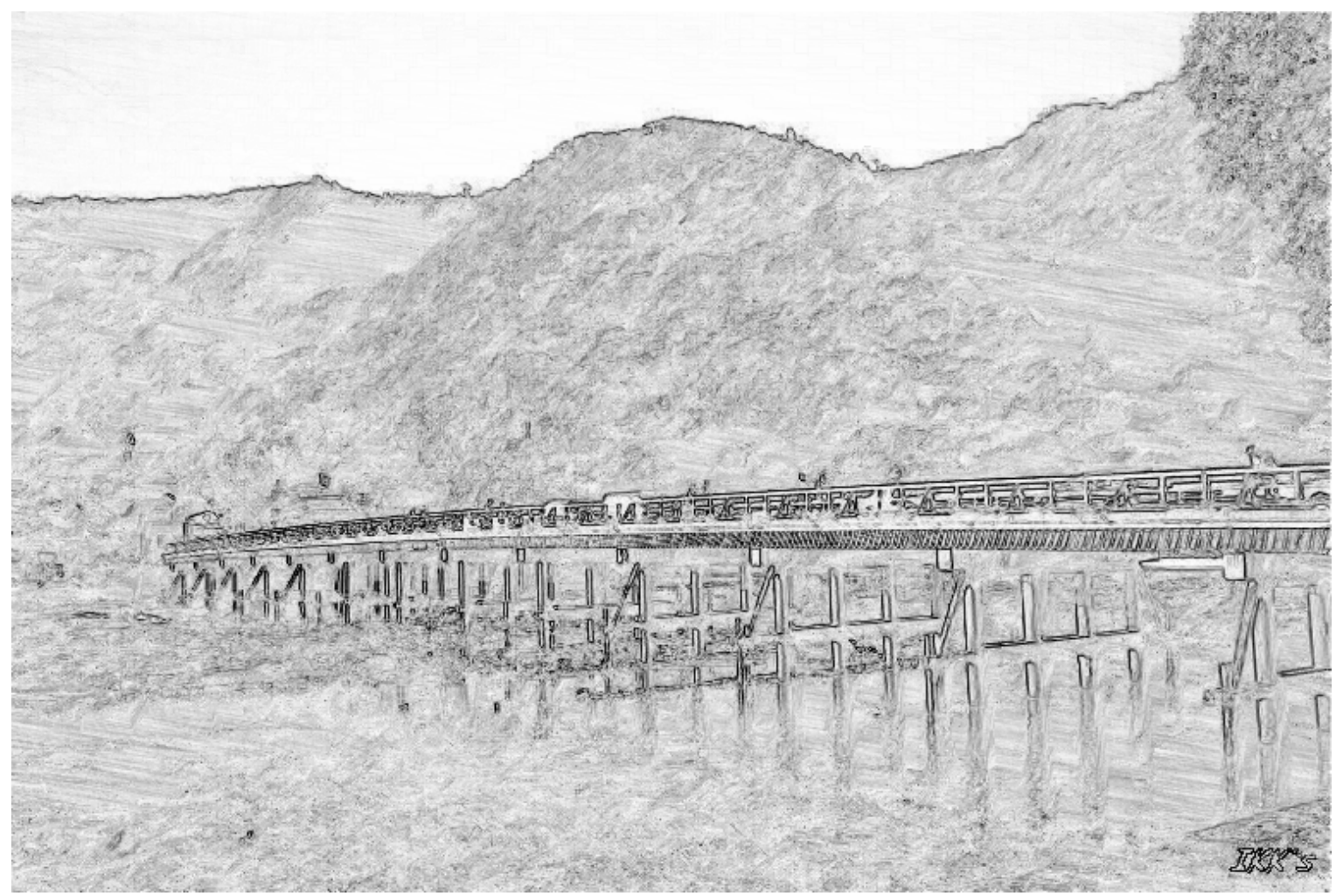

(b)

図 10: 入力写真(a)から自動生成された鉛筆画(b).

画像提供 : http://matsu.pos.to/ 


\section{5. まとめと今後の課題}

本論文では，LIC 法を用いて自動的に 2 次元画像 から鉛筆画を生成するアルゴリズムを提案した。ス トロークの方にそって定義された 1 次元のフィル タカーネルを用いてホワイトノイズを畳み込むだけ で, 入力画像のトーン分布に合致した鉛筆画が生成 できることが示された．ストロークの方向もテクス チャの方向を考慮して自動的に決定できた. NPR の 目的はアーティストに代わることではなく，特定の 描画法の訓練を受けたことのないユーザにも適切な 描画ツールを提供することも大きな目的の一つであ る.この観点からみると, 自動的に結果が生成でき るかどうかは，NPR 技法の有用性を大きく左右する 要因であると考えられる. 提案手法が利用される可 能性のあるフィールドとしては, 写真からのポスタ 一製作，ビデオからの鉛筆画風アニメーション製作 などが考えられる.

今後の研究課題として, 自動生成寸る画像の品質 のさらなる向上があげられる.人間が描く場合は, オブジェクトの位置や重要度, そして表面テクスチ ヤなどに合わせてストロークの太さや長さなど変え ながら描画する. 我々のシステムでは現在, 領域に よってストロークの太さや長さを変えることはでき ない. 2 次元画像を入力としているため, オブジェ クトの奥行きに関する情報や重要度に関する情報を 自動抽出することは困難であるが，テクスチャ解析 によりテクスチャの粒度を検出し, 粒度に合わせて ストロークの太さを調整することは可能と思われる. ストロークのスタイルに関してもより進んだモデル 化が必要である. トーンの連続変化に加えて, スト ロークの形や方向は通常オブジェクトの形状を伝え る上で重要である. 例えば, 球形のオブジェクトで あれば, 輪郭線にそったストロークで描くのが自然 である，そのようなストロークを自動生成する課題 は, 入力が 2 次元画像であることを考えるときわめ て挑戦的である.Kim らはストロークモーフィング と呼ばれる技術を提案した $[23]$. 彼らのペン画生成 法では, ユーザがいくつかのサンプルストロークと 配置方向を与え, これをもとにシステムがモーフィ
ングにより描画に必要なストロークを自動生成する. このようにあまり負担になることなくユーザに必要 最小限の情報を入力してもらうことも解決法の一つ として考えられる. 我々のシステムでも現在, ユー ザが対話的に領域と領域内のストローク方向 (一つ) を指定できる．ただし，一つの領域全体が指定され た方向で描画されるので, 対象物の形状にそった自 然な描き方が得られない場合がある。今後は Kim ら の手法の実装を含め, ユーザの嗜好を簡単に反映で きるようシステムにも改善していく予定である.

もうひとつ困難な課題は, 抽象化とフォーカシン グの実現である，アーティストは，ありのままにシ ーンのディテールを描くわけではなく, 主題に深く 関係したオブジェクトを強調し，不必要な箇所は削 ってしまう。そのような抽象化と省略は芸術的メデ イアを写実的なメディアから差別化する最も重要な 特徵である。第 3 章で述べたように，そのような機 能を自動的に実現することは難しい. なぜなら，抽 象化と省略に関する客観的な共通規則は知られてお らず，それらはアーティストの個性に立脚するもの であるからである。しかし，画像処理技術を援用し て, 最低限の機能支援は行っていきたい. 例えば, 入力画像の構成と色配分を調查することによって, 個別化されたフォーカシングに関する情報を抽出で きる可能性も残されている [24]. また, 前述した ストロークの指定の場合と同様に，負担にならない 程度にユーザに情報を入力してもらう方法も考えら れる。

\section{謝辞}

本稿の執筆にあたり, 多くの貴重なコメントをい ただいたお茶の水女子大学の藤代一成教授及び査読 者の方々に深謝の意を表す.

\section{参考文献}

[1] 大野義夫，「フォトリアルでないCG画像表現の 手法について」, 情報処理学会グラフィクスと CAD研究会, 95-CG-76, pp.1-7,1995.

[2] B. Gooth and A. Gooth, Non-Photorealistic Rendering, A K Peters, 2001. 
[3] A. Hertzmann, "Painterly Rendering with Curved Brush Strokes of Multiple Sizes," SIGGRAPH 98 Conference Proceedings, pp.453-460, 1998.

[4] P. Litwinowicz, "Proceeding Images and Video for An Impressionist Effect," SIGGRAPH97 Conference Proceedings, pp.407-414, 1997.

[5] C. J. Curtis, S. E. Anderson, J. E. Seims, Kurt W. Fleischer, and David H. Salesin, “Computer-Generated Watercolor," SIGGRAPH 97 Conference Proceedings, pp.421-430, 1997.

[6] G. Winkerbach, D. H. Salesin, "Computer-Generated Pen-and-Ink Illustration," SIGGRAPH94 Conference Proceedings, pp.91-100, 1994.

[7] Mike Salisbury, Corin Anderson, Dani Lischinski, David H. Salesin: "Scale-Dependent Reproduction of Pen-and-Ink Illustrations", SIGGRAPH96 Conference Proceedings, pp.461-468,1996.

[8] M. P. Salisbury, M. T. Wong, J. F. Hughes, and D. H. Salesin, "Orientable Textures for Image-Based Pen-and-Ink Illustration,” SIGGRAPH 97 Conference Proceedings, pp.401-406, 1997.

[9] 旭昌広, 近藤邦雄, 島田静雄, 佐藤尚,「イラ スト作画支援システムの開発」, 第7 回 NICOGRAPH 論女コンテス卜論女集, pp.22-31,1991.

[10] 近藤邦雄, 神原章, 佐藤尚, 島田静雄, 「レン ダリングのための対話型線画表現法」, 図学研 究, No.55,pp.11-15,1992.

[11] .A. KANBARA, K. KONDO, H. SATO, S. SHIMADA, "Interactive Rendering System for Line Drawings by Dot and Line Shading", Proceedings of CG International'94, pp.172-179,1994.

[12] 中川大介, 山口恵介, 藤本忠博, 村岡一信, 千 葉則茂, 「濃淡画像からペン画調画像への変換 法 - 線描、点描-」, 画像電子学会誌, Vol.30,No.4,pp.350-361, 2001.

[13] S. Takagi, I. Fujishiro and M. Nakajima, "Volumetric Modeling of Colored Pencil Drawing," Pacific Graphics '99 Conference Proceedings, pp.
$250-258,1999$

[14] 高木佐恵子,藤代一成，「水溶性色えんぴつ画に おける加水効果のCGモデリング」，情報処理学 会グラフィクスとCAD研究会，96-CG-80-6, pp.25-32, 1996.

[15] M.C.Sousa and J.W.Buchanan, "Observational Model of Blenders and Erasers in Computer-Generated Pencil Rendering," Graphics Interface '99 Conference Proceedings, pp.157-166, 1999.

[16] M.C.Sousa and J.W.Buchanan, "Computer-Generated Graphite Pencil Rendering of 3D Polygonal Models," EUROGRAPHICS '99 Conference Proceedings, pp.195-207, 1999.

[17] A. H. Vermeulen and P. P. Tanner, "PencilSketch A Pencil-Based Paint System," Graphics Interface '89 Conference Proceedings, pp.138-143 , 1989.

[18] B. Cabral and C. Leedom, "Imaging Vector Field Using Line Integral Convolution," SIGGRAPH93 Conference Proceeding, pp.263-270, 1993.

[19] 齋藤 豪,中嶋 正之，「計算機による手描き風画 像の自動生成に関する研究」, テレビジョン学 会誌， Vol.50, No.10, pp.1528-1535, 1996.

[20] A.L. Guptill, Rendering in Pencil, Watson-Guptill Publications Inc., New York, 1977.

[21] 田村 秀行(編), コンピュータ画像処理入門, 総 研出版, 1984.

[22] フォーラム 11 : 入門シリーズ編, 鉛筆アート, 遊友出版, 1998.

[23] Hey-Sun Kim, Hee-Jeong Jin, Young-Jung Yu, Hwan-Gue Cho, "Creating pen-and-ink illustration using stroke morphing method", Proceedings of Computer Graphics International 2001.

[24] 近藤 邦雄, プライベートコミュニケーショ ン, 2001 年 2 月. 